\title{
Bone Cancer Pathologic Distant Metastasis TNM Finding v7
}

National Cancer Institute

\section{Source}

National Cancer Institute. Bone Cancer Pathologic Distant Metastasis TNM Finding v7. NCl Thesaurus. Code C88438.

A pathologic finding about one or more characteristics of bone cancer, following the rules of the TNM AJCC V7 classification system as they pertain to distant metastases. There is no pathologic Mo for bone cancer. 